\title{
Selective Vinyl Functionalization of Octakis(dimethylsiloxy)- octasilsesquioxane with Allylbenzene and 1,5-Hexadiene and Copolymerization of the Products with Bis(dimethylsilyl)benzene
}

\author{
Makoto SEINO and Yusuke KAWAKAMI ${ }^{\dagger}$ \\ Graduate School of Materials Science, Japan Advanced Institute of Science and Technology (JAIST), \\ 1-1 Asahidai, Tatsunokuchi, Ishikawa 923-1292, Japan
}

(Received January 13, 2004; Accepted March 4, 2004; Published May 15, 2004)

\begin{abstract}
Vinyl-functionalized cubic silsesquioxanes were prepared from octakis(dimethylsiloxy)octasilsesquioxane via hydrosilylation with 6, 5, and 4 equiv. of allylbenzene followed by the reaction with excess 1,5-hexadiene. The content of hexenyl groups in the silsesquioxanes was determined by ${ }^{1}$ H NMR and MALDI-TOF MS. Polyaddition by hydrosilylation of these compounds with bis(dimethylsilyl)benzene afforded polymers with moderate molecular weight soluble in common organic solvents. Chemical structure and thermal stability of the polymers were characterized by NMR, IR, and TGA. [DOI 10.1295/polymj.36.422]

KEY WORDS Octakis(dimethylsiloxy)octasilsesquioxane / Allylbenzene / 1,5-Hexadiene / Bis(dimethylsilyl)benzene / Hydrosilylation / MALDI-TOF MS / Soluble Polymer /
\end{abstract}

Organic-inorganic hybrid materials with well-defined structure have attracted a great deal of attention as they show not only synergistic properties, but can also be tailored for specific technical applications. Polyhedral oligomeric silsesquioxane (POSS), particularly the cubic silsesquioxane is an interesting class of inorganic component. It has nanometer-size cubic structure with wide surface area and controlled porosity, and can be functionalized with a wide variety of organic groups as monomer in a typical polymerization. Use of POSS derivatives as monomer has been demonstrated to be an efficient method in the design of nanocomposite materials ${ }^{1-15}$ as well as in designing various hybrid polymers with POSS as side groups ${ }^{16-28}$ or as chain end, ${ }^{29-31}$ which exhibit desirable unique properties. Laine et al. reported the synthesis of multi-functinal POSS as precursors of nanocomposite materials from commercially available typical silane-functionalized cubic silsesquioxane, octakis(dimethylsiloxy)octasilsesquioxane $\left(\mathrm{Q}_{8} \mathrm{M}_{8}{ }^{\mathrm{H}}\right)$ by hydrosilylation. ${ }^{6,7,9-11}$

Although many POSS-based nanocomposite materials or hybrid polymers have been prepared, only few papers have reported the synthesis of soluble polymer with POSS in main chain, ${ }^{32-36}$ since cubic silsesquioxane has eight corners, and it is difficult to control the number and position of the functional groups to be introduced. Even efforts to directly introduce two functional groups selectively to POSS succeeded insufficiently.

In this paper, we studied selective introduction of two polymerizable vinyl groups to $\mathrm{Q}_{8} \mathrm{M}_{8}{ }^{\mathrm{H}}$ via hydro- silylation with allylbenzene as capping reagent, followed by reaction of unreacted $\mathrm{SiH}$ groups with 1,5hexadiene to introduce polymerizable groups. Copolymerization of the products with bis(dimethylsilyl)benzene was also investigated to obtain soluble hybrid polymer with POSS in main chain.

\section{EXPERIMENTAL}

\section{General}

NMR $\left({ }^{1} \mathrm{H}, 500 \mathrm{MHz} ;{ }^{13} \mathrm{C}, 125.5 \mathrm{MHz} ;{ }^{29} \mathrm{Si}, 99.5\right.$ $\mathrm{MHz}$ ) spectra were obtained in $\mathrm{CDCl}_{3}$ on a Varian Unity INOVA. Chemical shifts are reported in ppm relative to internal $\mathrm{CHCl}_{3}\left(7.26,{ }^{1} \mathrm{H}\right), \mathrm{CDCl}_{3}(77.00$, $\left.{ }^{13} \mathrm{C}\right)$, and external tetramethylsilane $\left(0.00,{ }^{29} \mathrm{Si}\right)$. Analytical and preparative size exclusion chromatography (SEC) were performed on a JASCO chromatograph, model Gulliver 900. Combinations of Shodex KF801 and KF-802 (exclusion limit $M_{\mathrm{n}}=5.0 \times 10^{3}$ ), KF-803L and KF-804 (exclusion limit $M_{\mathrm{n}}=4.0 \times$ $10^{5}$ ), and KF-805L and KF-806L (exclusion limit $M_{\mathrm{n}}=2.0 \times 10^{7}$ ) columns were used for molecular weight analyses, and two KF-2001 and KF-2002 (exclusion limit $M_{\mathrm{n}}=5.0 \times 10^{3}$ ) columns for isolation of the products. THF was used as an eluent at a flow rate of $1 \mathrm{~mL} / \mathrm{min}$ for analysis and $2 \mathrm{~mL} / \mathrm{min}$ for isolation of the products. IR spectra were obtained on a JASCO VALOR-III spectrophotometer. Matrix-assisted laser desorption/ionization time-of-flight mass spectra (MALDI-TOF MS) were taken on a Shimadzu Kratos Kompact MALDI III. The matrix 2,5-dihydroxybenzoic acid (DHBA) was dissolved in THF

${ }^{\dagger}$ To whom correspondence should be addressed (E-mail: kawakami@jaist.ac.jp). 
$(50 \mathrm{mg} / \mathrm{mL})$, and mixed with the sample solution $(1 \mathrm{mg} / \mathrm{mL}$ in THF) in 1:1 v/v ratio. The samples were spotted onto the target and dried in air. The measurements were done in linear mode. Spectra were calibrated by the use of external calibration reagent, Bradykinin and Insulin B chain were used. The thermogravimetric analyses (TGA) were performed on a Seiko SSC $/ 5200 \mathrm{H}$ instrument at a heating rate of $5^{\circ} \mathrm{C} / \mathrm{min}$ under nitrogen.

\section{Materials}

Solvents were dried by standard procedures and distilled before use. Allylbenzene and 1,5-hexadiene were purchased from Aldrich Chemical Co., Inc. and distilled from calcium hydride. Platinum 1,3-divinyl-1,1,3,3-tetramethyldisiloxane complex solution in xylene (2.1-2.4 wt\%-Pt) [Pt(dvs)] and octakis(dimethylsiloxy)octasilsesquioxane $\left(\mathrm{Q}_{8} \mathrm{M}_{8}{ }^{\mathrm{H}}\right)$ were purchased from AZmax Co., Ltd. 1,4-Bis(dimethylsilyl)benzene (BSB) was prepared from 1,4-dibromobenzene and dimethylchlorosilane by Grignard reaction. 2,5-Dihydroxybenzoic acid (DHBA) was purchased from Aldrich Chemical Co., Inc.

Synthesis of Phenylpropyldimethylsiloxy- and Hexenyldimethylsiloxy-substituted Cubic Silsesquioxane (1a)

To a $15 \mathrm{~mL}$ Schlenk flask were added $\mathrm{Q}_{8} \mathrm{M}_{8}{ }^{\mathrm{H}}$ $(0.305 \mathrm{~g}, 0.3 \mathrm{mmol})$, allybenzene $(0.213 \mathrm{~g}, 1.8 \mathrm{mmol})$, and toluene $(3 \mathrm{~mL})$ under Argon. Pt(dvs) $(10 \mu \mathrm{L})$ was added, and the mixture was stirred at room temperature for $12 \mathrm{~h}$. After 1,5-hexadiene $(2 \mathrm{~mL})$ was added, the mixture was stirred for additional $24 \mathrm{~h}$. The products were filtered through a short Florisil ${ }^{\circledR}$ column $\left(\mathrm{Et}_{2} \mathrm{O}\right.$ eluent), and isolated by preparative SEC. Removal of the solvent gave a viscous colorless liquid 1a $(0.370 \mathrm{~g}$, yield $65 \%) .{ }^{1} \mathrm{HNMR}: \delta 0.08-0.13(\mathrm{~m}$, $\left.48 \mathrm{H}, \mathrm{SiCH}_{3}\right), 0.56-0.60\left(\mathrm{~m}, 4 \mathrm{H}, \mathrm{CH}_{2}=\mathrm{CH}\left(\mathrm{CH}_{2}\right)_{3}-\right.$ $\left.\mathrm{CH}_{2} \mathrm{Si}\right), 0.61-0.67\left(\mathrm{~m}, 12 \mathrm{H}, \mathrm{Ph}\left(\mathrm{CH}_{2}\right)_{2} \mathrm{CH}_{2} \mathrm{Si}\right), 1.30$ $1.42\left(\mathrm{~m}, 8 \mathrm{H}, \mathrm{CH}_{2}=\mathrm{CHCH}_{2}\left(\mathrm{CH}_{2}\right)_{2} \mathrm{CH}_{2} \mathrm{Si}\right), 1.61-1.69$ (m, $12 \mathrm{H}, \mathrm{PhCH}_{2} \mathrm{CH}_{2} \mathrm{CH}_{2} \mathrm{Si}$ ), 2.02 (q, $4 \mathrm{H}, \mathrm{CH}_{2}=\mathrm{CH}-$ $\mathrm{CH}_{2}\left(\mathrm{CH}_{2}\right)_{3} \mathrm{Si}, J=7.5 \mathrm{~Hz}$ ), 2.60 (sext, $12 \mathrm{H}, \mathrm{PhCH}_{2}$ $\left.\left(\mathrm{CH}_{2}\right)_{2} \mathrm{Si}, J=7.5 \mathrm{~Hz}\right), 4.91-4.99\left(\mathrm{~m}, 4 \mathrm{H}, \mathrm{H}_{2} \mathrm{C}=\mathrm{CH}\right)$, 5.74-5.83 (m, 2H, $\left.\mathrm{CH}_{2}=\mathrm{CHCH}_{2}\right), 7.13-7.17(\mathrm{~m}, \mathrm{Ph}$, $18 \mathrm{H}), 7.23-7.27(\mathrm{~m}, \mathrm{Ph}, 12 \mathrm{H}) .{ }^{13} \mathrm{C}$ NMR: $\delta-0.33$, $17.46,22.44,24.99,32.51,33.49,39.52,114.20$, 125.60, 128.21, 128.46, 138.97, 142.48. ${ }^{29}$ Si NMR: $\delta$ $-108.84,12.67,12.78$. IR (neat, $\mathrm{cm}^{-1}$ ): 3064,3028 , $2958,2926,2860,1642,1605,1497,1455,1410$, 1346, 1254, 1171, 1090, 841, 795, 764, 746, 698. MALDI-TOF MS (m/e): 1960, 1925, 1890, 1856, 1819, 1784, 1753.

1b $(0.300 \mathrm{~g}$, yield $54 \%)$ ([allylbenzene $] /\left[\mathrm{Q}_{8} \mathrm{M}_{8}{ }^{\mathrm{H}}\right]=$ 5) and 1c $(0.234 \mathrm{~g}$, yield 42\%) ([allylbenzene]/ $\left.\left[\mathrm{Q}_{8} \mathrm{M}_{8}{ }^{\mathrm{H}}\right]=4\right)$ were prepared similarly. Their NMR and IR Data were similar to 1a. MALDI-TOF MS $(m / e)$ for 1b: 1961, 1926, 1889, 1854, 1819, 1784, 1747, 1712, 1674; for 1c: $1960,1925,1889,1853$, 1817, 1780, 1733, 1698, 1662.

\section{Polymerization}

To a $15 \mathrm{~mL}$ Schlenk flask were added 1a $(0.370 \mathrm{~g}$, $0.195 \mathrm{mmol})$, BSB $(0.036 \mathrm{~g}, 0.187 \mathrm{mmol})$, and toluene $(1.9 \mathrm{~mL})$ under Argon. Pt $(\mathrm{dvs})(10 \mu \mathrm{L})$ was added, and the mixture was stirred for $18 \mathrm{~h}$. The products were filtered through a short Florisil ${ }^{\circledR}$ column ( $\mathrm{Et}_{2} \mathrm{O}$ eluent). Removal of the solvent gave a yellowish materials P1 [0.389 g, yield 96\%, SEC (exclusion limit $M_{\mathrm{n}}=$ $\left.\left.4.0 \times 10^{5}\right): M_{\mathrm{w}} / M_{\mathrm{n}}=12900 / 3300\right]$. The higher molecular weight fraction was isolated by reprecipitation from $\mathrm{Et}_{2} \mathrm{O}$ into methanol [0.180 g, yield $44 \%$, SEC (exclusion limit $\left.M_{\mathrm{n}}=4.0 \times 10^{5}\right): M_{\mathrm{w}} / M_{\mathrm{n}}=16800 /$ 6000]. ${ }^{1} \mathrm{H}$ NMR: $\delta$ 0.06-0.15 (br, $48 \mathrm{H},-\mathrm{OSi}\left(\mathrm{CH}_{3}\right)_{2}-$ $\left.\mathrm{CH}_{2}-\right), 0.23$ (s, $\left.12 \mathrm{H},-\mathrm{C}_{6} \mathrm{H}_{4} \mathrm{Si}\left(\mathrm{CH}_{3}\right)_{2} \mathrm{CH}_{2}-\right), 0.57$ (br, 4H, $-\mathrm{OSiMe}_{2} \mathrm{CH}_{2} \mathrm{CH}_{2}-$ ), 0.64 (br, $12 \mathrm{H}, \mathrm{Ph}-$ $\left(\mathrm{CH}_{2}\right)_{2} \mathrm{CH}_{2} \mathrm{Si}$ ), 0.72 (br, $4 \mathrm{H},-\mathrm{C}_{6} \mathrm{H}_{4} \mathrm{SiMe}_{2} \mathrm{CH}_{2} \mathrm{CH}_{2}-$ ), 1.29 (br, $16 \mathrm{H},-\mathrm{C}_{6} \mathrm{H}_{4} \mathrm{SiMe}_{2} \mathrm{CH}_{2}\left(\mathrm{CH}_{2}\right)_{4} \mathrm{CH}_{2} \mathrm{SiMe}_{2} \mathrm{O}-$ ), 1.66 (br, $12 \mathrm{H}, \mathrm{PhCH}_{2} \mathrm{CH}_{2} \mathrm{CH}_{2} \mathrm{Si}$ ), 2.61 (br, $12 \mathrm{H}$, $\left.\mathrm{PhCH}_{2}\left(\mathrm{CH}_{2}\right)_{2} \mathrm{Si}\right), 7.12-7.19$ (br, Ph, $\left.18 \mathrm{H}\right), 7.23-7.30$ (br, $\mathrm{Ph}, 12 \mathrm{H}), 7.47$ (s, $\left.\mathrm{C}_{6} \mathrm{H}_{4}, 4 \mathrm{H}\right) .{ }^{13} \mathrm{CNMR}: \delta$ $-3.06,-0.32,15.64,17.45,17.71,22.93,23.90$, $24.99,33.17,33.44,39.51,125.60,128.21,128.47$, 132.78, 140.19, 142.48. ${ }^{29} \mathrm{SiNMR}: \quad \delta \quad-108.75$, $-3.26,12.75,12.89$. IR (neat, $\mathrm{cm}^{-1}$ ): 3063, 3028, 2957, 2923, 2857, 1605, 1497, 1455, 1409, 1379, 1346, 1253, 1171, 1090, 839, 796, 765, 746, 698.

P2 were prepared from $\mathbf{1 b}(0.300 \mathrm{~g}, 0.161 \mathrm{mmol})$, BSB $(0.043 \mathrm{~g}, 0.221 \mathrm{mmol})$, and toluene $(2.2 \mathrm{~mL})$ similarly $[0.325 \mathrm{~g}$, yield $95 \%$, SEC (exclusion limit $\left.\left.M_{\mathrm{n}}=2.0 \times 10^{7}\right): \quad M_{\mathrm{w}} / M_{\mathrm{n}}=165000 / 6500\right] . \quad$ The higher molecular weight fraction was also isolated by reprecipitation $[0.118 \mathrm{~g}$, yield $34 \%$, SEC (exclusion limit $\left.M_{\mathrm{n}}=2.0 \times 10^{7}\right): \quad M_{\mathrm{w}} / M_{\mathrm{n}}=384700 /$ 15300]. Their NMR and IR Data were similar to P1.

\section{RESULTS AND DISCUSSION}

The POSS monomers with different content of vinyl groups $(\mathbf{1 a}-\mathbf{c})$ were synthesized by two step hydrosilylation as shown in Scheme 1. In order to cap a part of the $\mathrm{SiH}$ groups, $\mathrm{Q}_{8} \mathrm{M}_{8}{ }^{\mathrm{H}}$ were reacted with 6,5 , and 4 equiv. of allylbenzene in toluene for $12 \mathrm{~h}$ with $\mathrm{Pt}(\mathrm{dvs})$ as catalysts. Subsequently, unreacted $\mathrm{SiH}$ groups were reacted with excess 1,5-hexadiene for $24 \mathrm{~h}$ for vinyl functionalization. The size exclusion chromatograms (SEC) of the products are shown in Figure 1.

In the chromatograms, the peaks of desired product 1a-c were observed accompanied by oligomeric products depending on the feed ratio of allylbenzene to $\mathrm{Q}_{8} \mathrm{M}_{8}{ }^{\mathrm{H}}$. 1a-c was isolated by preparative SEC. With 


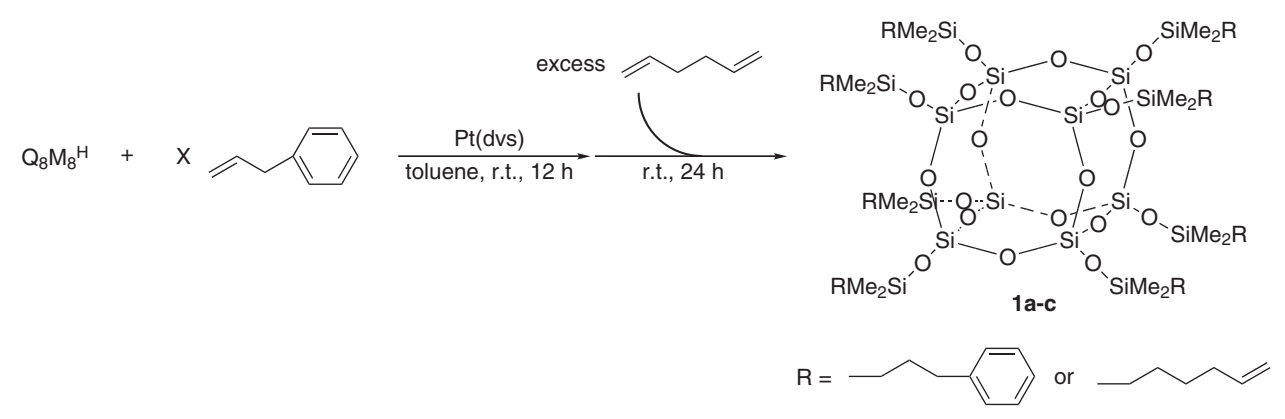

Scheme 1. Synthesis of vinyl-functionalized POSS monomers $1 \mathbf{a}(X=6), \mathbf{1 b}(X=5)$ and $\mathbf{1 c}(X=4) .{ }^{\text {a }}$ The position of substituents are not specified.

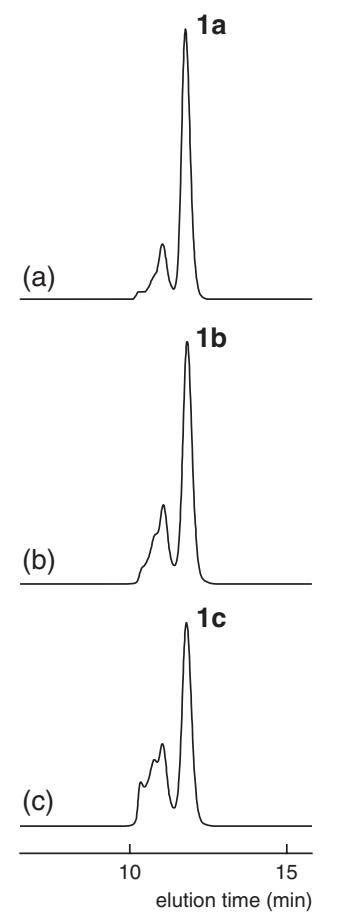

Figure 1. Change in SEC of the products with the feed ratio of allylbenzene to $\mathrm{Q}_{8} \mathrm{M}_{8}{ }^{\mathrm{H}}$ (X): (a) $\mathrm{X}=6$, (b) $\mathrm{X}=5$, (c) $\mathrm{X}=4$.

the decrease of allylbenzene in the feed ratio, the oligomeric fractions increased. It is considered that oligomers are easily formed when higher concentration of unreacted $\mathrm{SiH}$ groups remains, where hexadiene acts as bi-functional compound to connect POSS groups.

${ }^{1} \mathrm{H},{ }^{13} \mathrm{C}$, and ${ }^{29} \mathrm{Si}$ NMR spectra of $\mathbf{1 a}-\mathbf{c}$ exhibited clean signals reflecting chemical structure of the produced POSS derivatives. The spectra of $\mathbf{1 a}$ are shown in Figure 2. In ${ }^{1} \mathrm{HNMR}$ (Figure 2a), vinyl protons were observed at 4.91-4.99 and 5.74-5.83 ppm. Aliphatic protons of 5-hexenyl groups were observed at $0.56-0.60,1.30-1.42$, and $2.02 \mathrm{ppm}$, and those of 3phenylpropyl groups at $0.61-0.67,1.61-1.69$, and $2.60 \mathrm{ppm}$, respectively. Methyl proton of $\mathrm{SiCH}_{3}$ appeared as complicated signals at $0.08-0.13 \mathrm{ppm}$, because 1a is a mixture of POSS with the two substituents of various compositions at different positions.
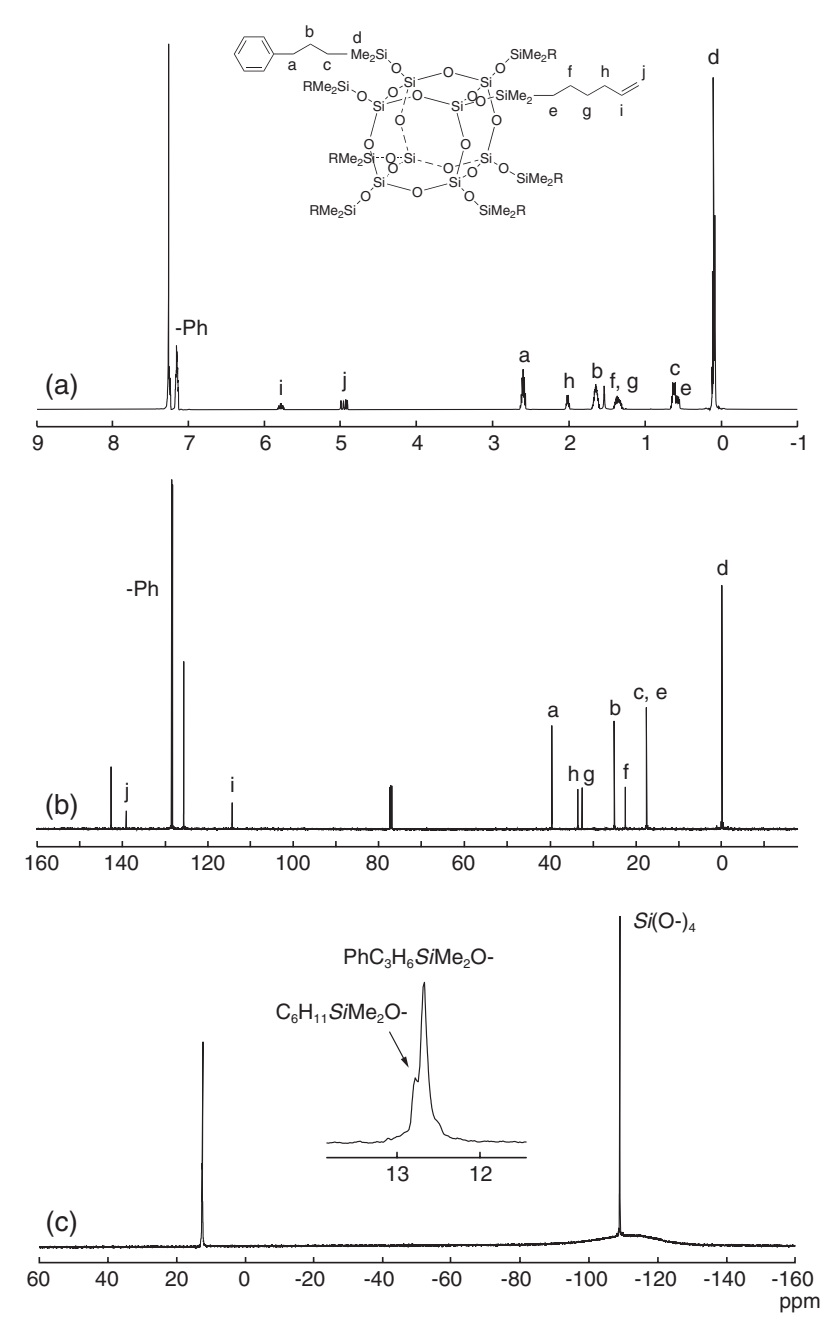

Figure 2. ${ }^{1} \mathrm{H}(\mathrm{a}),{ }^{13} \mathrm{C}$ (b), and ${ }^{29} \mathrm{Si}(\mathrm{c}) \mathrm{NMR}$ spectra of $\mathbf{1 a}$.

The content of hexenyl groups was estimated by integral ratio of methylene protons at $2.02 \mathrm{ppm}$ (hexenyl groups) and those at $2.60 \mathrm{ppm}$ (phenylpropyl groups). Average molecular weights of $\mathbf{1 a}-\mathbf{c}$ were calculated as 1894 (1a), 1865 (1b), and 1840 (1c) by Eq 1. The contents of hexenyl groups, yields, and average molecular weights of 1a-c are summarized in Table I. The content of hexenyl groups almost agrees with the feed ratio. When the feed ratio of allylbenzene was decreased, the content of hexenyl groups became smaller than 
Table I. Compositions of substituents on POSS monomers (1a-c)

\begin{tabular}{ccccc}
\hline Monomer & $\mathrm{X}^{\mathrm{a}}$ & $\begin{array}{c}\text { Ratio of hexenyl/phenylpropyl } \\
\left(\mathrm{A}_{\mathrm{h}} / \mathrm{A}_{\mathrm{p}}\right)^{\mathrm{b}}\end{array}$ & $\begin{array}{c}\text { Average } \\
\text { molecular weight }^{\mathrm{c}}\end{array}$ & $\begin{array}{c}\text { Yield }^{\mathrm{d}} \\
(\%)\end{array}$ \\
\hline 1a & 6 & $1.92 / 6.08$ & 1894 & 65 \\
1b & 5 & $2.74 / 5.26$ & 1865 & 54 \\
1c & 4 & $3.42 / 4.58$ & 1840 & 42 \\
\hline
\end{tabular}

${ }^{\mathrm{a}}$ [allylbenzene]/[Q $\left.\mathrm{Q}_{8} \mathrm{M}_{8}{ }^{\mathrm{H}}\right] .{ }^{\mathrm{b}}$ Determined by ${ }^{1} \mathrm{H}$ NMR. ${ }^{\mathrm{c}}$ Calculated value by Eq $1 .{ }^{\mathrm{d}}$ Isolated yield by preparative SEC.

the theoretical value. It is probably caused by consumption of hexenyl groups in the formation of oligomers. The decrease in yield was similar.

Molecular Weight (MW) of $\mathbf{1}$

$$
=1009.91+119.18 \mathrm{~A}_{\mathrm{p}}+83.15 \mathrm{~A}_{\mathrm{h}}
$$

1009.91: MW of $\mathrm{Q}_{8} \mathrm{M}_{8}$

119.18: MW of $\mathrm{PhC}_{3} \mathrm{H}_{6}$

83.15: $\mathrm{MW}$ of $\mathrm{C}_{6} \mathrm{H}_{11}$

$\mathrm{A}_{\mathrm{p}}$ : relative integral area of $\mathrm{PhC}_{3} \mathrm{H}_{6}$

$A_{h}$ : relative integral area of $\mathrm{C}_{6} \mathrm{H}_{11}$

$A_{p}+A_{h}=8$

The ${ }^{13} \mathrm{C}$ NMR spectrum showed clear signals (Figure $2 \mathrm{~b}$ ). The signals at 114.20 and $138.97 \mathrm{ppm}$ are vinyl carbon, and 17.46, 22.44, 32.51, and $33.49 \mathrm{ppm}$ are aliphatic carbon of hexenyl groups. The signals of phenylpropyl groups were observed at 17.46, $24.99,39.52,125.60,128.21,128.46$, and 142.48 ppm. Carbons of $\mathrm{SiCH}_{2}$ of hexenyl groups appeared at $17.46 \mathrm{ppm}$ as overlapped signal with those in phenylpropyl groups. The signal at $-0.33 \mathrm{ppm}$ is methyl carbon of $\mathrm{SiCH}_{3}$. The DEPT spectrum did not show the existence of $\mathrm{CH}$-carbon arisen from $\alpha$-addition, indicating that hydrosilylation proceeded selectively via $\beta$-addition. The ${ }^{29} \mathrm{SiNMR}$ spectrum exhibited three signals (Figure 2c). The signals at 12.78 and 12.67 ppm are ascribed to $\mathrm{C}_{6} \mathrm{H}_{11} \mathrm{SiMe}_{2}\left(\mathrm{O}_{-}\right)$and $\mathrm{PhC}_{3} \mathrm{H}_{6}$ $\mathrm{SiMe}_{2}(\mathrm{O}-)$, and that at $-108.84 \mathrm{ppm}$ to silicon atom of cubic structure $\mathrm{Si}(\mathrm{O}-)_{4}$.

In addition to spectral investigations, 1a-c were characterized by MALDI-TOF MS, which has become an extremely valuable tool for the investigation and characterization of silsesquioxane in the last few years. ${ }^{37-46}$ Figure 3 shows the mass spectra in the $1500-2100 \mathrm{~m} / \mathrm{z}$ range, using DHBA as matrix. 1a-c gave spectra corresponding to their $[\mathrm{M}+\mathrm{H}]^{+}$ions. In all case, several peaks were observed and could be ascribed to general formula of $\mathrm{Q}_{8} \mathrm{M}_{8}\left(\mathrm{C}_{6} \mathrm{H}_{11}\right)_{m^{-}}$$\left(\mathrm{C}_{3} \mathrm{H}_{6} \mathrm{Ph}\right)_{n}$. In the spectrum of 1a (Figure 3a), although seven components $(m=0-6)$ were observed, those with one or two hexenyl $\left(\mathrm{C}_{6} \mathrm{H}_{11}\right)$ groups $(m=$ $1,2)$ were formed as major components. The component with $m=1$ was observed as the highest peak for 1a. The intensity of the peak became weaker with the

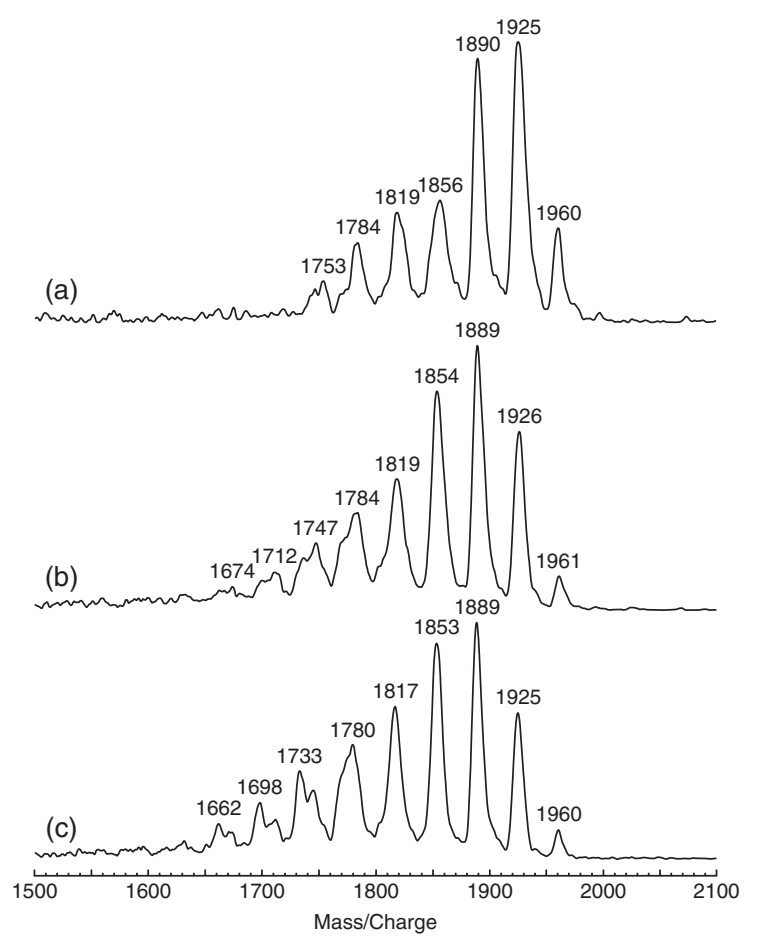

Figure 3. MALDI-TOF MS of 1a-c: (a) 1a, (b) 1b, (c) 1 c.

decrease of the feed of allylbenzene, and the peaks with $m=2-8$ became stronger. In the spectra of $\mathbf{1 b}$ and 1c (Figure 3b, c), components with $m=1-4$ were formed in similar concentration as major products. The assignments of the peaks are summarized in Table II. Agreement between calculated and experimental values was excellent and comprised within experimental error. These results indicated that intramolecular cyclization of $\mathrm{SiH}$ group and hexenyl group was not involved in the reaction. The change of the peak intensity of the products also agreed with the change in integral area of ${ }^{1} \mathrm{H}$ NMR.

Polyaddition of 1a-c with BSB by hydrosilylation was carried out in toluene $\left(0.1 \mathrm{~mol} \mathrm{~L}^{-1}\right)$ at room temperature for $18 \mathrm{~h}$ with $\mathrm{Pt}(\mathrm{dvs})$ as shown in Scheme 2. With the higher concentration of $\mathbf{1 a - c}$ and BSB, the reaction mixture became insoluble. The equivalency of BSB to 1 was calculated by Eq 2 .

$$
[\mathrm{BSB}] /[\mathbf{1}]=\mathrm{A}_{\mathrm{h}} / 2
$$

$A_{h}$ is the same with Table I 
Table II. Assignments of MALDI-TOF-MS of 1a-c

\begin{tabular}{|c|c|c|c|c|}
\hline \multicolumn{3}{|c|}{ Exptl $m / z$} & \multirow{2}{*}{ Assignment } & \multirow{2}{*}{$\begin{array}{c}\text { Calcd } \\
{[\mathrm{M}+\mathrm{H}]^{+}}\end{array}$} \\
\hline $1 \mathbf{a}$ & $\mathbf{1 b}$ & $1 \mathrm{c}$ & & \\
\hline 1960 & 1961 & 1960 & $\mathrm{Q}_{8} \mathrm{M}_{8}\left(\mathrm{C}_{3} \mathrm{H}_{6} \mathrm{Ph}\right)_{8}$ & 1961 \\
\hline 1925 & 1926 & 1925 & $\mathrm{Q}_{8} \mathrm{M}_{8}\left(\mathrm{C}_{6} \mathrm{H}_{11}\right)\left(\mathrm{C}_{3} \mathrm{H}_{6} \mathrm{Ph}\right)_{7}$ & 1925 \\
\hline 1890 & 1889 & 1889 & $\mathrm{Q}_{8} \mathrm{M}_{8}\left(\mathrm{C}_{6} \mathrm{H}_{11}\right)_{2}\left(\mathrm{C}_{3} \mathrm{H}_{6} \mathrm{Ph}\right)_{6}$ & 1889 \\
\hline 1856 & 1854 & 1853 & $\mathrm{Q}_{8} \mathrm{M}_{8}\left(\mathrm{C}_{6} \mathrm{H}_{11}\right)_{3}\left(\mathrm{C}_{3} \mathrm{H}_{6} \mathrm{Ph}\right)_{5}$ & 1853 \\
\hline 1819 & 1819 & 1817 & $\mathrm{Q}_{8} \mathrm{M}_{8}\left(\mathrm{C}_{6} \mathrm{H}_{11}\right)_{4}\left(\mathrm{C}_{3} \mathrm{H}_{6} \mathrm{Ph}\right)_{4}$ & 1817 \\
\hline 1784 & 1784 & 1780 & $\mathrm{Q}_{8} \mathrm{M}_{8}\left(\mathrm{C}_{6} \mathrm{H}_{11}\right)_{5}\left(\mathrm{C}_{3} \mathrm{H}_{6} \mathrm{Ph}\right)_{3}$ & 1781 \\
\hline \multirow[t]{6}{*}{1753} & 1747 & & $\mathrm{Q}_{8} \mathrm{M}_{8}\left(\mathrm{C}_{6} \mathrm{H}_{11}\right)_{6}\left(\mathrm{C}_{3} \mathrm{H}_{6} \mathrm{Ph}\right)_{2}$ & 1745 \\
\hline & 1712 & & $\mathrm{Q}_{8} \mathrm{M}_{8}\left(\mathrm{C}_{6} \mathrm{H}_{11}\right)_{7}\left(\mathrm{C}_{3} \mathrm{H}_{6} \mathrm{Ph}\right)$ & 1709 \\
\hline & 1674 & & $\mathrm{Q}_{8} \mathrm{M}_{8}\left(\mathrm{C}_{6} \mathrm{H}_{11}\right)_{8}$ & 1673 \\
\hline & & 1733 & $\mathrm{Q}_{8} \mathrm{M}_{8}\left(\mathrm{C}_{6} \mathrm{H}_{11}\right)_{6}\left(\mathrm{C}_{3} \mathrm{H}_{6} \mathrm{Ph}\right)_{2}-\mathrm{Me}$ & 1730 \\
\hline & & 1698 & $\mathrm{Q}_{8} \mathrm{M}_{8}\left(\mathrm{C}_{6} \mathrm{H}_{11}\right)_{7}\left(\mathrm{C}_{3} \mathrm{H}_{6} \mathrm{Ph}\right)-\mathrm{Me}$ & 1694 \\
\hline & & 1662 & $\mathrm{Q}_{8} \mathrm{M}_{8}\left(\mathrm{C}_{6} \mathrm{H}_{11}\right)_{8}-\mathrm{Me}$ & 1658 \\
\hline
\end{tabular}

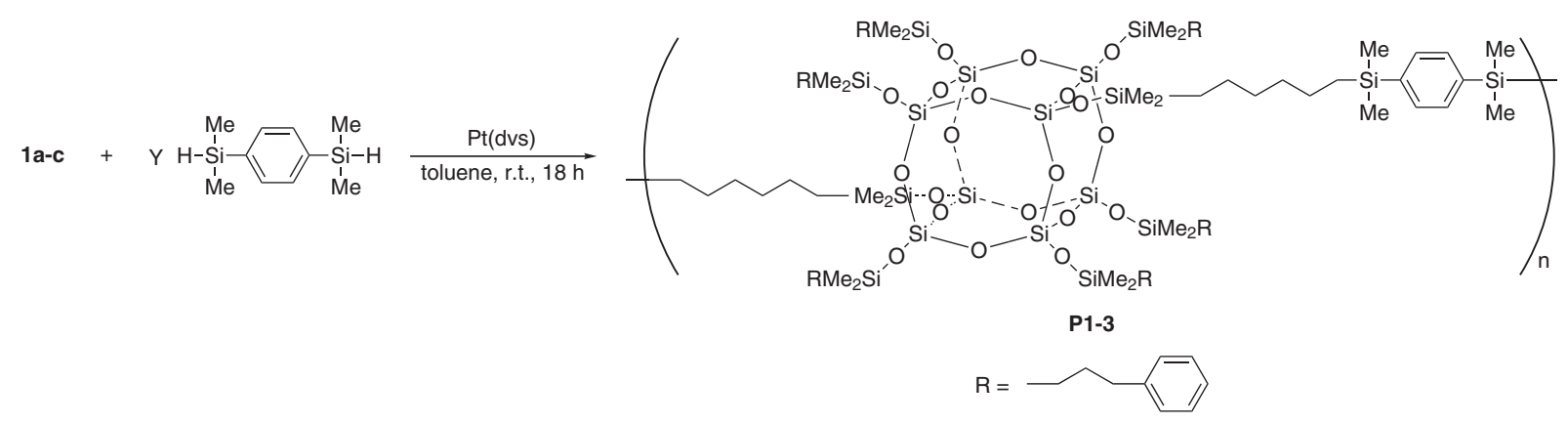

Scheme 2. Polyaddition by hydrosilylation of 1a-c with BSB.
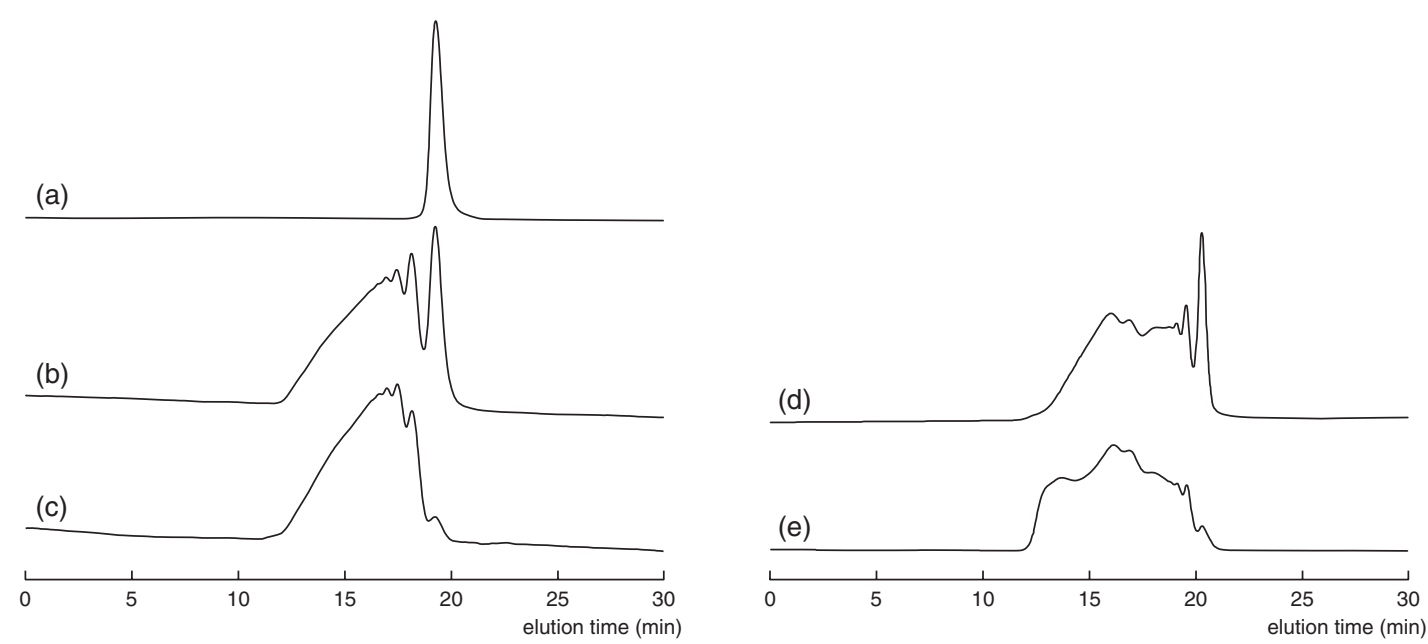

Figure 4. SEC of polymers: (a) 1a, (b) P1 as produced, (c) P1 after reprecipitation, (d) P2 as produced, (e) $\mathbf{P 2}$ after reprecipitation.

The SEC of the polymers are shown in Figure 4 (KF803L and KF804 columns for P1, KF805L and KF806L for P2), and the results of polymerization are summarized in Table III. P1 was obtained in good yield as soluble products, but the molecular weight is not high and polydispersity is very broad with multimodal distribution $\left(M_{\mathrm{w}} / M_{\mathrm{n}}=12900 / 3300\right.$, Figure 4b). Apparent monomer fraction at $19.27 \mathrm{~min}$ in the product, presumably completely phenylpropyl-capped 1a, could be removed by reprecipitation into metha- nol, and the higher molecular weight fraction was isolated $\left(M_{\mathrm{w}} / M_{\mathrm{n}}=16800 / 6000\right.$, Figure $\left.4 \mathrm{c}\right)$. P1 was soluble in most common organic solvents, such as acetone, chloroform, methylene chloride, ethyl acetate, hexane, and toluene, except methanol.

P2 was also obtained in good yield. The molecular weight and polydispersity are higher and broader than P1 $\left(M_{\mathrm{w}} / M_{\mathrm{n}}=165000 / 6500\right.$, Figure 4d). Branching degree might have increased with the increase in the content of vinyl groups in $\mathbf{1 b}$ compared with 1a, nev- 
Table III. Polymerization conditions and the molecular weights

\begin{tabular}{ccccccc}
\hline Polymer & Monomer & $\mathrm{Y}^{\mathrm{a}}$ & $\begin{array}{c}\text { Yield }^{\mathrm{b}} \\
(\%)\end{array}$ & $M_{\mathrm{n}}{ }^{\mathrm{c}}$ & $M_{\mathrm{w}}{ }^{\mathrm{c}}$ & PD $^{\mathrm{c}}$ \\
\hline P1 & 1a & 0.96 & $96(44)$ & $3300(6000)$ & $12900(16800)$ & $3.9(2.8)$ \\
P2 & 1b & 1.37 & $95(34)$ & $6500(15300)$ & $165000(384700)$ & $25.3(25.1)$ \\
P3 & 1c & 1.71 & insoluble & - & - & - \\
\hline
\end{tabular}

${ }^{\mathrm{a}}[\mathrm{BSB}] /[\mathbf{1}]$ calculated by Eq $2 .{ }^{\mathrm{b}}$ Isolated yield before (after) reprecipitation. ${ }^{\mathrm{c}}$ Determined by SEC with polystylene standerd.

ertheless the product was soluble in ethereal solvents. The higher molecular weight fraction of $\mathbf{P 2}$ could be isolated by reprecipitation $\left(M_{\mathrm{w}} / M_{\mathrm{n}}=384700 /\right.$ 15300, Figure 4e).

It should be noted that in the SEC of $\mathbf{P 2}$ after reprecipitation (Figure 4e), a shoulder peak appeared in the higher molecular weight region, and $\mathbf{P 2}$ became insoluble when left for a while after reprecipitation and drying. Few remaining vinyl and $\mathrm{SiH}$ groups in P2 may have caused cross-linking. Condensation of silanol function formed during reprecipitation might be the most probable reason. In the case of P1, such change in solubility was not observed.

1c, having higher concentration of vinyl groups than $\mathbf{1 b}$, was used to react BSB under the similar condition, however, the reaction mixture became insoluble after $1 \mathrm{~h}$. These results indicated that the solubility of the polymer is dependent on the content of vinyl groups in the POSS monomer.

The chemical structures of polymers were characterized by NMR and IR. ${ }^{1} \mathrm{H},{ }^{13} \mathrm{C}$, and ${ }^{29} \mathrm{Si}$ NMR of $\mathbf{P 1}$ are shown in Figure 5. The ${ }^{1} \mathrm{H}$ NMR showed broad signals (Figure 5a). The signals of vinyl protons of 1a completely disappeared. The signals of methyl and phenylene proton of BSB unit were observed at 0.23 and $7.47 \mathrm{ppm}$. In the ${ }^{13} \mathrm{CNMR}$ spectrum (Figure $5 b$ ), the signal of vinyl carbons also disappeared and the signals of addition product were observed. The signal of methyl carbon of BSB unit was observed at $-3.06 \mathrm{ppm}$ and phenylene carbon at 132.78 and $140.19 \mathrm{ppm}$. The DEPT spectrum did not show $\mathrm{CH}-$ carbon signals, similarly as mentioned above. The ${ }^{29} \mathrm{Si}$ NMR showed clear signals (Figure $5 \mathrm{c}$ ). In addition of three signals arisen from 1a, the signal of silicon of BSB unit was observed at $-3.26 \mathrm{ppm}$. These results indicated that the polymerization proceed without side reaction to produce polymer as shown in Scheme 2.

The thermal stability of monomer 1a-c, polymers $\mathbf{P 1}$ and $\mathbf{P 2}$ were studied by thermogravimetric analysis (TGA) and the results are represented in Figure 6. Monomer 1a-c showed on-set decomposition temperatures at 438,437 , and $436{ }^{\circ} \mathrm{C}$ and residue of 26.9 , 27.2 , and $25.8 \%$ at $1000{ }^{\circ} \mathrm{C}$. Even with the different content of hexenyl groups, no obvious difference
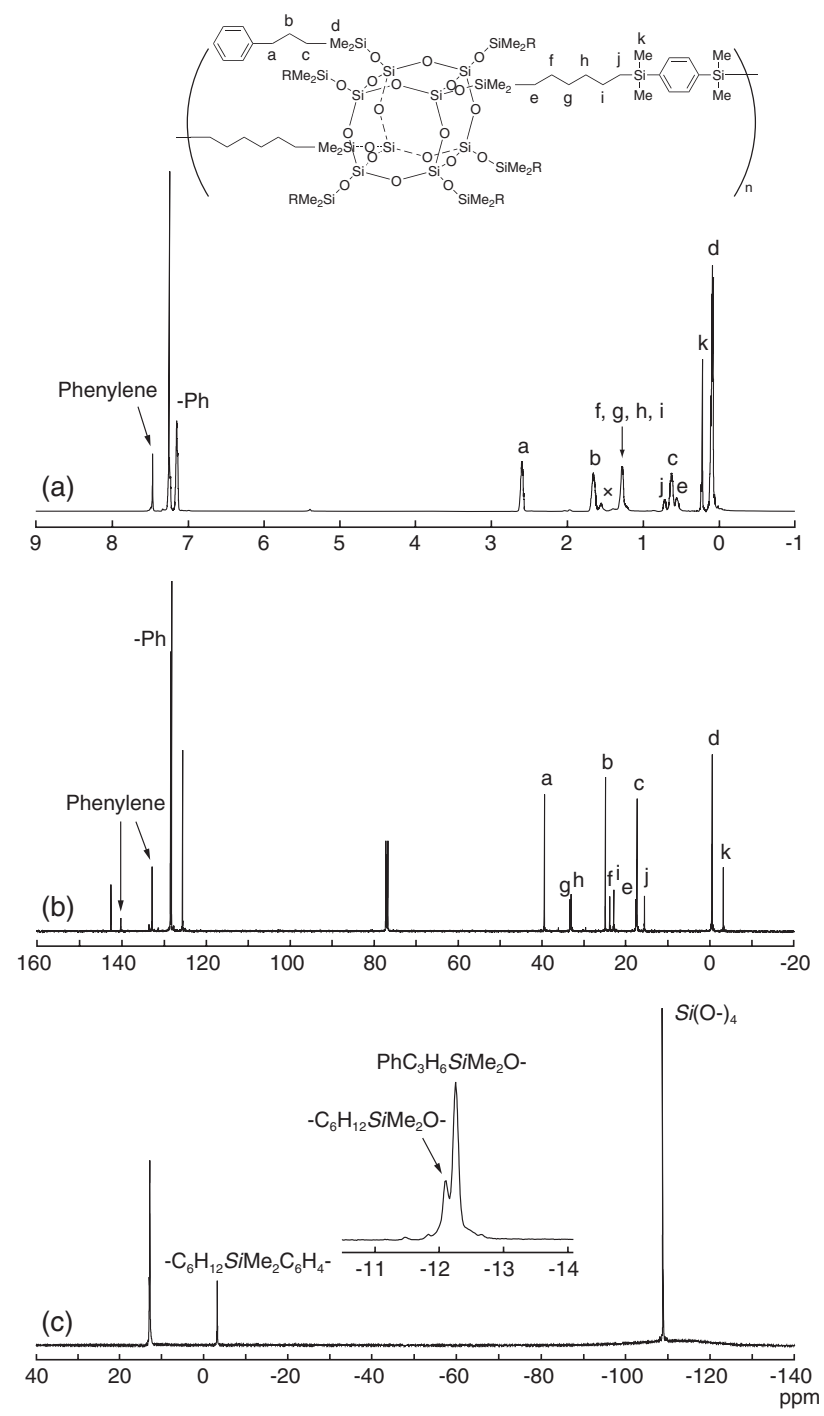

Figure 5. ${ }^{1} \mathrm{H}(\mathrm{a}),{ }^{13} \mathrm{C}(\mathrm{b})$, and ${ }^{29} \mathrm{Si}(\mathrm{c}) \mathrm{NMR}$ spectra of $\mathbf{P 1}$.

was observed in their on-set decomposition temperatures. The thermal stability of the polymer P1 and $\mathbf{P 2}$ increased by about $10^{\circ} \mathrm{C}$ compared to 1a-c. P1 and $\mathbf{P 2}$ exhibited on-set decomposition temperatures at 446 and $449{ }^{\circ} \mathrm{C}$ and residues of 24.4 and $19.0 \%$. The difference of thermal stability by the influence of the molecular weight was hardly observed.

\section{CONCLUSIONS}

Successful synthesis of a soluble organic-inorganic 


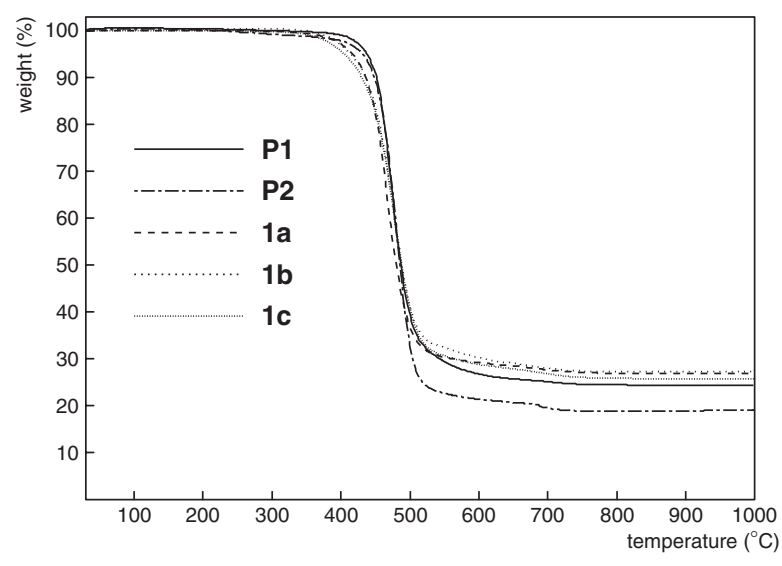

Figure 6. TGA of $\mathbf{1 a - c ,} \mathbf{P 1}$ and $\mathbf{P 2}$.

hybrid polymer with POSS units in backbone was described. The vinyl-functionalized POSS monomers were prepared from octakis(dimethylsiloxy)octasilsesquioxane $\left(\mathrm{Q}_{8} \mathrm{M}_{8}{ }^{\mathrm{H}}\right)$ via hydrosilylation with 6,5 , and 4 equiv. of allylbenzene, followed by reaction of unreacted $\mathrm{SiH}$ groups with excess hexadiene. The structural analysis of the monomers proved that reaction proceeded selectively in $\beta$-addition and did not involve any side reaction such as intramolecular cyclization of $\mathrm{SiH}$ group with hexenyl group to give monomers with general formula $\mathrm{Q}_{8} \mathrm{M}_{8}\left(\mathrm{C}_{6} \mathrm{H}_{11}\right)_{m}\left(\mathrm{C}_{3} \mathrm{H}_{6} \mathrm{Ph}\right)_{n}$. The content of hexenyl groups of POSS was determined by ${ }^{1} \mathrm{H}$ NMR and MALDI-TOF MS. Polyaddtition by hydrosilylation of these compounds with bis(dimethylsilyl)benzene afforded moderate molecular weight polymers soluble in common organic solvents. Thermal property of the polymers was improved a little by the incorporation of POSS unit in the polymer structure.

Acknowledgment. This work was also carried out partly in Nanotechnology Glass Project as part of Nanotechnology Materials Program supported by New Energy and Industrial Technology Development Organization (NEDO).

\section{REFERENCES}

1. P. G. Harrison, J. Organomet. Chem., 542, 141 (1997).

2. D. Hoebbel, K. Endres, T. Reinert, and I. Pitsch, J. NonCryst. Solids, 176, 179 (1994).

3. P. G. Harrison and R. Kannengiesser, Chem. Commun, 415 (1996).

4. G. Z. Li, L. Wang, H. Toghiani, T. L. Daulton, K. Koyama, and C. U. Pittman, Jr., Macromolecules, 34, 8686 (2001).

5. C. Zhang, F. Babonneau, C. Bonhomme, R. M. Laine, C. L. Soles, H. A. Hristov, and A. F. Yee, J. Am. Chem. Soc., 120, 8380 (1998).

6. C. Zhang and R. M. Laine, J. Am. Chem. Soc., 122, 6979 (2000).

7. J. Choi, J. Harcup, A. F. Yee, Q. Zhu, and R. M. Laine, J.
Am. Chem. Soc, 123, 11420 (2001).

8. R. Tamaki, Y. Tanaka, M. Z. Asuncion, J. Choi, and R. M. Laine, J. Am. Chem. Soc., 123, 12416 (2001).

9. A. Sellinger and R. M. Laine, Macromolecules, 29, 2327 (1996).

10. R. O. R. Costa, W. L. Vasconcelos, R. Tamaki, and R. M. Laine, Macromolecules, 34, 5398 (2001).

11. A. Sellinger and R. M. Laine, Chem. Mater., 8, 1592 (1996).

12. R. Tamaki, J. Choi, and R. M. Laine, Chem. Mater., 15, 793 (2003).

13. R. M. Laine, C. Zhang, A. Sellinger, and L. Viculis, Appl. Organometal. Chem., 12, 715 (1998).

14. J. V. Crivello and R. Malik, J. Polym. Sci., Part A: Polym. Chem., 35, 407 (1997).

15. D. Neumann, M. Fisher, L. Tran, and J. G. Matisons, J. Am. Chem. Soc., 124, 13998 (2002).

16. J. D. Lichtenhan, Y. A. Otonari, and M. J. Carr, Macromolecules, 28, 8435 (1995).

17. T. S. Haddad and J. D. Lichtenhan, Macromolecules, 29, 7302 (1996).

18. A. Tsuchida, C. Bolln, F. G. Sernetz, H. Frey, and R. Mülhaupt, Macromolecules, 30, 2818 (1997).

19. P. T. Mather, H. G. Jeon, A. Romo-Uribe, T. S. Haddad, and J. D. Lichtenhan, Macromolesules, 32, 1194 (1999).

20. J. Pyun and K. Matyjaszewski, Macromolecules, 33, 217 (2000).

21. L. Zheng, R. J. Farris, and E. B. Coughlin, Macermolecules, 34, 8034 (2001).

22. L. Zheng, A. J. Waddon, R. J. Farris, and E. B. Coughlin, Macromolecules, 35, 2375 (2002).

23. H. Xu, S. Kuo, J. Lee, and F. Chang, Macromolecules, 35, 8788 (2002).

24. W. Zhang, B. X. Fu, Y. Seo, E. Schrag, B. Hsiao, P. T. Mather, N. Yang, D. Xu, H. Ade, M. Rafailovich, and J. Sokolov, Macromolecules, 35, 8029 (2002).

25. M. J. Abad, L. Barral, D. P. Fasce, and R. J. J. Williams, Macromolecules, 36, 3128 (2003).

26. J. B. Carroll, A. J. Waddon, H. Nakade, and V. M. Rotello, Macromolecules, 36, 6289 (2003).

27. B. X. Fu, B. S. Hsiao, S. Pagola, P. Stephens, H. White, M. Rafailovich, J. Sokolov, R. T. Mather, H. G. Jeon, S. Phillips, J. Lichtenhan, and J. Schwab, Polymer, 42, 599 (2001).

28. C. Leu, Y. Chang, and K. Wei, Chem. Mater., 15, 3721 (2003).

29. B. Kim and P. T. Mather, Macromolecules, 35, 8378 (2002).

30. K. Kim, D. Keum, and Y. Chujo, Maceomolecules, 36, 867 (2003).

31. C. Leu, G. M. Reddy, K. Wei, and C. Shu, Chem. Mater., 15, 2261 (2003).

32. J. D. Lichtenhan, N. Q. Vu, J. A. Carter, J. W. Gilman, and F. J. Feher, Macromolecules, 26, 2141 (1993).

33. R. A. Mantz, P. F. Jones, K. P. Chaffee, J. D. Lichtenhan, and J. W. Gilman, Chem. Mater., 8, 1250 (1996).

34. M. E. Wright, D. A. Schorzman, F. J. Feher, and R. Jin, Chem. Mater., 15, 264 (2003).

35. T. Kobayashi, T. Hayashi, and M. Tanaka, Chem. Lett., 1998, 763.

36. T. S. Haddad and J. D. Lichtenhan, J. Inorg. Organomet. 
Polym., 5, 237 (1995).

37. R. E. Tecklenburg, W. E. Wallace, and H. Chen, Rapid Commun. Mass Spectrom., 15, 2176 (2001).

38. D. P. Fasce, R. J. J. Williams, R. Erra-Balsells, Y. Ishikawa, and H. Nonami, Macromolecules, 34, 3534 (2001).

39. B. Dereese, P. Smet, F. Verpoort, L. Verdonck, and J. Van Beeumen, Rapid Commun. Mass Spectrom., 12, 1204 (1998).

40. I. E. dell' Erba, D. P. Fasce, R. J. J. Williams, R. ErraBalsells, Y. Fukuyama, and H. Nonami, J. Organomet. Chem, 686, 42 (2003).

41. D. R. Bujalski, H. Chen, R. E. Tecklenburg, E. S. Moyer, G. A. Zank, and K. Su, Macromolecules, 36, 180 (2003).
42. P. Eisenberg, R. Erra-Balsells, Y. Ishikawa, J. C. Lucas, A. N. Mauri, H. Nonami, C. C. Riccardi, and R. J. J. Williams, Macromolecules, 33, 1940 (2000).

43. J. Falkenhagen, H. Jancke, R. Krüger, E. Rikowski, and G. Schulz, Rapid Commun. Mass Spectrom., 17, 285 (2003).

44. R. J. J. Williams, R. Erra-Balsells, Y. Ishikawa, H. Nonami, A. N. Mauri, and C. C. Riccardi, Macromol. Chem. Phys., 202, 2425 (2001).

45. W. E. Wallace, C. M. Guttman, and J. M. Antonucci, J. Am. Soc. Mass Spectrom., 10, 224 (1999).

46. P. Eisenberg, R. Erra-Balsells, Y. Ishikawa, J. C. Lucas, H. Nonami, and R. J. J. Williams, Macromolecules, 35, 1160 (2002). 